Document downloaded from:

http://hdl.handle.net/10251/141640

This paper must be cited as:

Camilleri-Rumbau, MDLS.; Soler-Cabezas, JL.; Christensen, KV.; Norddahl, B.; Mendoza Roca, JA.; Vincent Vela, MC. (01-0). Application of aquaporin-based forward osmosis membranes for processing of digestate liquid fractions. Chemical Engineering Journal. 371:583-592. https://doi.org/10.1016/j.cej.2019.02.029

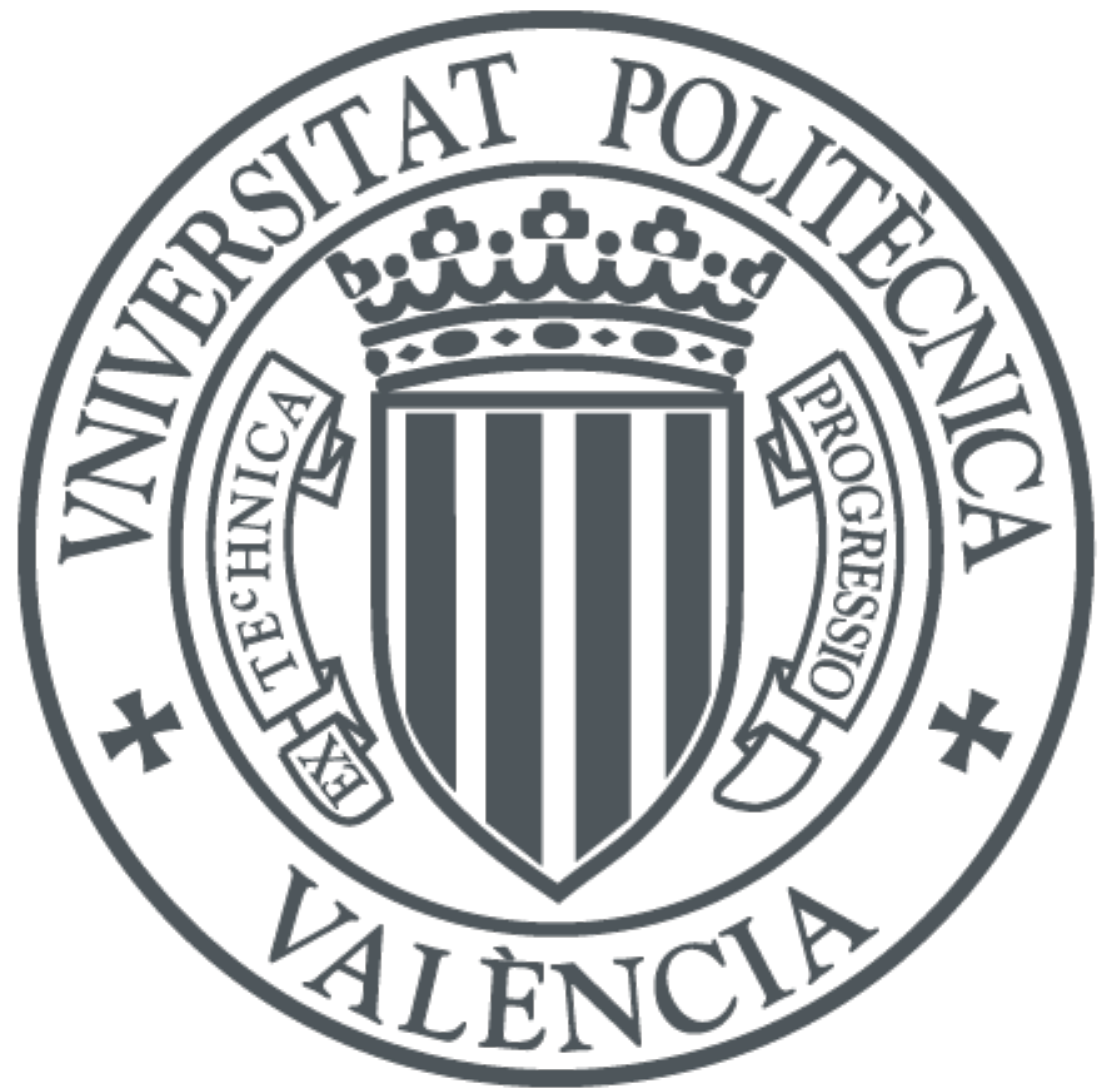

The final publication is available at

https://doi.org/10.1016/j.cej.2019.02.029

Copyright Elsevier

Additional Information 


\section{Accepted Manuscript}

Application of aquaporin-based forward osmosis membranes for processing of digestate liquid fractions

Maria Salud Camilleri-Rumbau, Jose Luis Soler-Cabezas, Knud V. Christensen, Birgir Norddahl, Jose Antonio Mendoza-Roca, Maria Cinta Vincent-Vela

PII:

S1385-8947(19)30246-3

DOI: https://doi.org/10.1016/j.cej.2019.02.029

Reference:

CEJ 20941

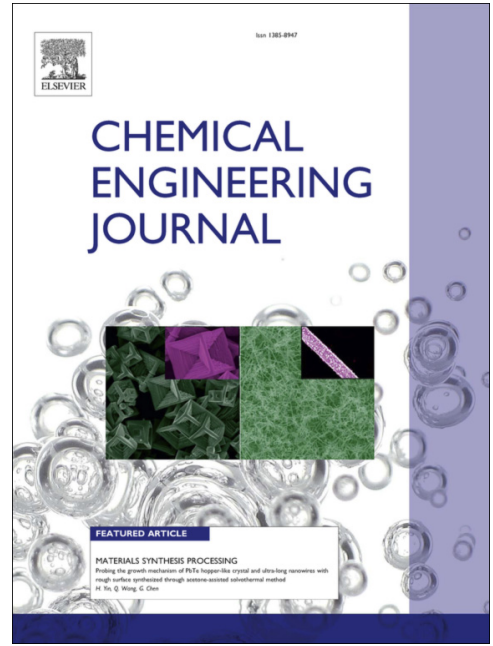

To appear in:

Chemical Engineering Journal

Received Date:

11 December 2018

Revised Date:

1 February 2019

Accepted Date:

4 February 2019

Please cite this article as: M.S. Camilleri-Rumbau, J.L. Soler-Cabezas, K.V. Christensen, B. Norddahl, J.A. Mendoza-Roca, M.C. Vincent-Vela, Application of aquaporin-based forward osmosis membranes for processing of digestate liquid fractions, Chemical Engineering Journal (2019), doi: https://doi.org/10.1016/j.cej.2019.02.029

This is a PDF file of an unedited manuscript that has been accepted for publication. As a service to our customers we are providing this early version of the manuscript. The manuscript will undergo copyediting, typesetting, and review of the resulting proof before it is published in its final form. Please note that during the production process errors may be discovered which could affect the content, and all legal disclaimers that apply to the journal pertain. 


\title{
Application of aquaporin-based forward osmosis membranes for processing of digestate liquid fractions
}

Camilleri-Rumbau, Maria Salud ${ }^{\mathrm{a} *}$, Soler-Cabezas, Jose Luis ${ }^{\mathrm{b}}$, Christensen, Knud V. ${ }^{\text {a }}$, Norddahl, Birgir ${ }^{\mathrm{a}}$, Mendoza-Roca, Jose Antonio ${ }^{\mathrm{b}}$, Vincent-Vela, Maria Cinta.

${ }^{a}$ Department of Chemical Engineering, Biotechnology and Environmental Technology, University of Southern Denmark, 5230 Odense M, Denmark

${ }^{\mathrm{b}}$ Institute for Industrial, Radiophysical and Environmental Safety, Universitat Politècnica de València, 46022 Valencia, Spain

* Corresponding author: macarum@googlemail.com

Keywords: forward osmosis, digestate liquid fraction; hide preservation wastewater; total ammonianitrogen rejection (TAN); membrane rinsing; membrane fouling

\begin{abstract}
Forward osmosis is a low-energy water treatment emerging technology, which has demonstrated improved solute rejection and low fouling propensity. In this study, the applicability of aquaporinbased forward osmosis membranes during separation of biogas digestate liquid fractions was investigated. The results showed that Total Ammonia-Nitrogen rejection was higher than 95.5\% in all experiments, independently of the type of draw solution ( $\mathrm{NaCl}$ and hide preservation effluents), experimental period and the use of feed acidification. The results also confirmed that high draw osmotic pressures (i.e. 3.5M sodium chloride and hide preservation wastewater) combined with feed acidification had a negative effect on the membrane water permeability. Membrane rinsing after fouling was also successful in recovering the membrane initial water flux as well as removing
\end{abstract}


the remaining foulants on the membrane surface. The membrane inspection results from ScanningElectron Microscope, Energy-Dispersive X-Ray analysis and Fourier Transform InfraredAttenuated Total Reflectance showed that fouling in this application was mild and reversible after membrane rinsing. The applicability of aquaporin-based forward osmosis membranes during separation of biogas digestate liquid fractions has been demonstrated. The results showed the potential of this technology to achieve enhanced ammonia-nitrogen rejections and low-fouling propensity.

\section{Introduction}

Manure treatment and management is getting increased attention. Especially in areas with intensive farming, manure poses a potential pollution threat for air and water bodies. In this regard, anaerobic digestion has proved to improve manure fertilizer quality, reduce odours, allow energy recovery and produce biogas as a renewable fuel [1]. By applying anaerobic co-digestion of manure with agricultural feedstocks, an energy efficiency of 45-55\% approximately can be obtained [2]. However, a purification step of the biogas for removing $\mathrm{CO}_{2}$ and other impurities needs to be considered, especially if the biogas is intended to be upgraded in the form of natural gas and supplied in the natural gas grid. These purification techniques can involve physical and chemical absorption, pressure swing adsorption, membrane separation, etc., being membrane contactors for gas absorption a highly efficient and promising alternative [3], [4]. Additionally, the digestates obtained after anaerobic digestion can be further separated into a solid and a liquid fraction (LF) that can be applied in agriculture. However, the fertilizer composition of these fractions remains unbalanced, [5]-[7] which reduces the efficiency of reusing digestate fractions as organic fertilizers in agriculture. Membrane technology has shown promising results in the context of anaerobic digestion, when applied during separation of digestate and raw manure LFs and when combining feed acidification and filtration to obtain an increased ammonia-nitrogen recovery [8]-[12]. 
However, there are few disadvantages when using pressure-driven membrane technologies. These disadvantages are mainly related to the high energy requirements and membrane fouling propensity, which increase the operating costs at farm level [12], [13]. As an alternative to pressure-driven membrane processes, forward osmosis (FO) could be of interest in those applications where low energy usage is required, lower water fluxes $\left(J_{w}\right)$ can be allowed and the treatment of the final brine is possible [14]. Additionally, FO has also shown higher rejections of pollutants as compared to other membrane techniques [15], which could be of special interest during nutrient recovery from waste streams [16]. However, FO presents some limitations related to the presence of concentration polarization on both sides of the membrane (external concentration polarization - ECP, and dilutive internal concentration polarization - ICP), which hinders permeation across the membrane, leading to a much lower attained $J_{w}$ in the FO process than the one expected theoretically [17], [18]. In this regard, biomimetic aquaporin FO membranes have introduced few advantages over traditional FO membranes. These advantages include increased $J_{w}$, lower reverse salt fluxes $J_{s}$ and high solute rejections, thanks to the incorporation of selective water channel proteins, which only allow water to pass through, rejecting all other compounds [19].

The application of FO in the real world has also been hindered by the lack of an ideal draw solution (DS). Ideally, a DS should provide a high osmotic potential and an ease for regeneration to produce pure water [20]. Industrial effluents with high salinity could be considered good candidates as DSs, without the need of any further regeneration or dilution steps before being discharged. In this paper, hide preservation wastewater (HPWW) from beam house operations in the tannery industry has been introduced as a DS for FO application. Tannery industry is known as one of the most polluting existing process industries, with effluents from beam house operations having conductivities as high as $200 \mathrm{mS} \cdot \mathrm{cm}^{-1}$ [21]-[23], being these effluents responsible for $76 \%$ of the total polluting charge produced during the hide manufacturing processes [24]. Apart from their high salt concentrations, tannery effluents are also rich in nitrogen compounds, especially organic nitrogen, 
but very poor in phosphorous, which makes their biological treatment difficult [25], [26].

Therefore, it is interesting to explore the applicability of these highly saline effluents as a potential candidate for a DS during FO.

In this study, the applicability of biomimetic aquaporin FO membranes for processing digestate LF from animal waste has been assessed. To date, there are few studies focusing on the application of FO membranes for processing digestate LF [27]-[30]. The membranes were examined in terms of membrane performance $\left(J_{w}, J_{s}\right)$, ammonia-nitrogen rejection and post-mortem membrane surface characterization after rinsing. Furthermore, the role of the selected DS (a model sodium chloride $\mathrm{NaCl}$ solution and an effluent from tannery industry) was evaluated, as well as the effect of feed acidification.

\section{Materials and methods}

\subsection{Feed solutions}

Two feed solutions (FS) were used during the experiments. Deionized (DI) water $\left(\sim 5 \mu \mathrm{S} \cdot \mathrm{cm}^{-1}\right)$ was used during water permeability tests to obtain the membrane baseline. The real FS was cow digestate LF. The digestate LF samples were collected from a biogas plant in Sant Esteve de Guialbes (Girona, Spain). The digestates were generated by anaerobic co-digestion of cow manure (83.4\%) and other organic substrates (16.6\%), and mechanically separated in a solid and a liquid fraction by means of a decanter centrifuge (Bauer $\mathrm{GmbH})$. The physico-chemical characteristics of the obtained LF are shown in Table 1 and Table 2. The pH of the FS fraction averaged 8.4 (Table 1). The elemental composition of the unmeshed samples (Table 2) was, in decreasing concentrations, calcium $(\mathrm{Ca})>$ potassium $(\mathrm{K})>$ phosphorus $(\mathrm{P})>\operatorname{sodium}(\mathrm{Na})$, which are commonly found elements in digestates and animal waste [8]. Due to the high coarse solid content of the obtained digestate LF, sample pre-meshing was necessary to avoid damaging the membranes. 
Previous studies on digestates LFs have described that particles mean and median sizes vary from 31 to $257 \mu \mathrm{m}$ and from 14 to $116 \mu \mathrm{m}$, respectively [31]. Based on this, it is reasonable to select a sieve mesh size of $2 \mathrm{~mm}, 350 \mu \mathrm{m}$ and $125 \mu \mathrm{m}$ to remove the coarse solids present in the studied LFs to mitigate potential membrane surface damages or excessive fouling [32]. Pre-meshing reduced total solids of the LF from $49 \mathrm{~g} \mathrm{~L}^{-1}$ to $36 \mathrm{~g} \mathrm{~L}^{-1}$ after meshing with $350-125 \mu \mathrm{m}$ sieving. The resulting sample was then diluted to simulate a commonly used thinner digestate LF with a total solid content of $20 \mathrm{~g} \cdot \mathrm{L}^{-1}$, approximately [8], [9].

FS acidification was also evaluated for selected experiments. Concentrated sulfuric acid $\left(\mathrm{H}_{2} \mathrm{SO}_{4}\right.$ 96\%, ISO. 131058.1611, AppliChem Panreac) was added to pre-meshed FS until reaching a pH 6.7 \pm 0.2 , following previous work [12]. Sodium hydroxide $(\mathrm{NaOH}$ pellets for analysis, AppliChem Panreac) was used to readjust the $\mathrm{pH}$ when needed. The $\mathrm{pH}$ of the FS was not adjusted during the experiment to avoid any disturbances on the conductivity readings. After acidification, it was noted that the FS conductivity increased slightly on average from 9.2 to $11.2 \mathrm{mS} \cdot \mathrm{cm}^{-1}$.

\subsection{Draw solutions}

Two draw solutions (DS) were used during the experiments. A model $\mathrm{NaCl}$ solution and a hide preservation wastewater (HPWW) source. For membrane characterization purposes, several concentrations of $\mathrm{NaCl}$ solutions (technical $\mathrm{NaCl}$, VWR chemicals, Prolabo) were prepared at 25, 50, 100, 150, $200 \mathrm{~g} \cdot \mathrm{L}^{-1} \mathrm{NaCl}(0.43,0.85,1.7,2.6,3.5 \mathrm{M}$, respectively) (Figure 2). For experiments using digestate $\mathrm{LF}$ with model $\mathrm{NaCl}$ as a $\mathrm{DS}, 1.1 \mathrm{M}$ and $3.5 \mathrm{M} \mathrm{NaCl}$ solutions were used. The HPWW source, with an osmotic pressure equivalent to $3.5 \mathrm{M} \mathrm{NaCl}$ approximately (Table 1), was collected from a tannery factory in the region of Murcia (Spain). This effluent was rich in sulfate, presented a basic $\mathrm{pH}>10$ (Table 1), green coloration and an intense sulfur smell. For ensuring a safe handling of HPWW during the experiments, the samples were pretreated using desulfurization and prolonged aeration. Aeration was used in both pretreatments (EHEIM, air pump 100). 
Desulfurization of HPWW was further assisted with a manganese (II) sulfate $\left(\mathrm{MnSO}_{4}\right)$ catalyzer. The aeration was maintained for 5 days. Parallelly, prolonged aeration was allowed for a minimum period of 24 hours. After both pre-treatments, the HPWW samples were pre-meshed using a $60 \mu \mathrm{m}$ cartridge filter to ensure removal of any precipitates.

\subsection{Laboratory scale plant}

Figure 1 shows the FO laboratory setup. A Sterlitech CF042 cross membrane flow cell was used during the experiments. The FS and DS were placed in separated plastic containers. FS was stirred continuously. The DS weight was logged continuously from a scale (Kern PKP, Germany) connected to a PC. Two peristaltic pumps (Hei-FLOW Advantage 06, Heidolph Instruments) were used for recirculating the FS and DS. Both solutions were recirculated in counter-flow during the experiments. Pressure readings were determined on the membrane feed side using an analog manometer (Nuova Fima). The conductivity of both the FS and DS were monitored and recorded using a high range conductivity meter (CDH-SD1 conductivity meter, Omega Engineering). The pH (HD 2305.0 pH-mV meter, Delta Ohm) of both FS and DS were measured at the beginning and at the end of each experimental run.

\subsection{Membranes and experimental procedures}

Aquaporin Inside ${ }^{\mathrm{TM}}$ FO flat sheet membranes (Aquaporin A/S, Denmark) were used for the experiments. The membrane is based on a thin film composite (TFC). The aquaporin protein reconstituted vesicles are embedded in a polyamide (PA) active layer on a sulfonated porous support (PSf). Membranes were soaked in DI water for a minimum period of 30 minutes before use, following manufacturer's recommendation. The membrane position was kept in FO mode (i.e. FS facing the active layer - FS-AL) for all the experiments. Both FS and DS pumps were adjusted to a flow rate of $30 \mathrm{~L} \cdot \mathrm{h}^{-1}$ (i.e. cross-flow velocity of $9.2 \mathrm{~cm} \cdot \mathrm{s}^{-1}$ ) for all experiments. Both FS and DS 
were run in batch mode. The pressure increase at the feed side was kept below 0.12 bar, to avoid membrane damage. Experiments were done at room temperature $\left(24 \pm 1^{\circ} \mathrm{C}\right)$. Sampling of FS and DS was done at the beginning and at the end of each experiment, and samples were stored at $4^{\circ} \mathrm{C}$ until further analysis. The membrane coupons were initially characterized in terms of osmotic $J_{w}$ and reverse solute flux $\left(J_{s}\right)$ using DI water and $\mathrm{NaCl}$ (see sections 2.1. and 2.2).

Experiments were performed using both a non-acidified and an acidified FS. The DS consisted of $\mathrm{NaCl}$ solutions (1.1M and 3.5 M NaCl) and pretreated HPWW (desulfurized and aerated HPWW). For each experiment, pristine membrane coupons were used. The volumetric concentration factor (VCF), defined as the ratio between the initial FS volume and the concentrate volume, was maintained at VCF $1.04 \pm 0.03$. All experiments were run for 180 minutes. After this fouling period, the membranes were rinsed and soaked in DI water. Membrane rinsing alone with DI water allows an increase in water flux by removal of soluble material or desorption of foulants [33]. Additionally, a longer experiment consisting of 12 hours fouling using non-acidified FS and 3.5M NaCl as a DS was also performed. This experiment was done in three fouling-rinsing intervals. After each 4 hourfouling step, the membrane was rinsed and soaked in DI water. Soaking in DI water allowed the thick fouling cake layer to detach from the membrane surface. All membrane surfaces were examined after soaking in DI water.

The osmotic water flux $J_{w}\left(\mathrm{~L} \cdot \mathrm{m}^{-2} \cdot \mathrm{h}^{-1}\right)$ was calculated following Equation 1 .

$$
J_{w}=\frac{\Delta m_{D S}}{\Delta t \times A_{m}}
$$

where $\Delta m_{D S}$ is the mass $(\mathrm{kg})$ or volume $(\mathrm{L})$ increase in the $\mathrm{DS}, \Delta \mathrm{t}$ is the time interval (h) and $\mathrm{A}_{\mathrm{m}}$ is the FO membrane area $\left(\mathrm{m}^{2}\right)$. 
The osmotic pressure $\pi$ (bar) of the studied solutions, FS and DS, was obtained following Equation 2.

$\pi=i M \mathrm{RT}$

where $i$ is the dimensionless van't Hoff factor for the selected solute ion, $M$ is the molarity of the specific ion, $R$ is the gas constant, and $T$ is the temperature. Results shown as water permeability $(K)$, were calculated as an average of $J_{w} / \Delta \pi$.

The reverse salt flux $J_{s}\left(\mathrm{~g} \cdot \mathrm{m}^{-2} \cdot \mathrm{h}^{-1}\right)$ was calculated following Equation 3 (adapted from [34].

$J_{s, i}=\frac{c_{F, i} \times\left[V_{F, i}-J_{w, i} \times A_{F O} \times\left(t_{i}-t_{0}\right)\right]-c_{F, 0} \times V_{F, 0}}{A_{F O} \times\left(t_{i}-t_{0}\right)}$

where $J_{s, i}$ is the reverse salt flux, $c_{F_{i}}$ is the concentration of solute in the FS (calculated from conductivity readings), $V_{F}$ is the volume of $\mathrm{FS}, A_{F O}$ is the membrane active area, $J_{\mathrm{w}, i}$ is the osmotic water flux through the semi-permeable membrane, $t_{i}$ is the experimental time elapsed.

\subsection{Analytical methods}

FS and DS samples were analyzed in terms of Total Ammonia-Nitrogen (TAN) (Manual Kjeldahl distiller, Pro-nitro, Selecta), Chemical Oxygen Demand (COD) (Hach Lange), Total organic Carbon (TOC) (Merck), Total Nitrogen (TN) (Hach Lange), Total solids (TS) [35], Total Phosphorus $\left(\mathrm{PO}_{4}{ }^{3-} \mathrm{P}\right)$ (Hach Lange), $\mathrm{pH}$ and conductivity. FS and HPWW elemental analysis (Table 2) was performed by ICP-OES (ICAP 6500 Duo, ThermoScientific). TAN analysis required diluting $5 \mathrm{~mL}$ of sample into $25 \mathrm{~mL}$ of DI water in a distillation tube. Ammonia-nitrogen was absorbed into $5 \mathrm{~mL}$ of $4 \%$ boric acid (VWR Chemicals Prolabo) with Mixed indicator 5 solution (VWR Chemicals Prolabo). For TAN volatilization, the distillation unit used $40 \% \mathrm{w} / \mathrm{w} \mathrm{NaOH}$ 
(AppliChem Panreac) and DI water. Titration was done with $\mathrm{HCl} 0.1 \mathrm{~N}$ (AVS Titrinorm, VWR Chemicals, Prolabo) and $\mathrm{HCl} 0.1 \mathrm{~N}$ titration volume was noted (Equation 4).

$$
[T A N]=\frac{V_{H C l} \times N \times 1000 \times A r_{N}}{m_{\text {sample }}}
$$

Where, $[\mathrm{TAN}]$ is the concentration of total ammonia-nitrogen $\left(\mathrm{mg} \cdot \mathrm{L}^{-1}\right) ; \mathrm{N}$ the normality of the titration acid $(0.1 \mathrm{~N} \mathrm{HCl})$; $\mathrm{V}$ the volume of acid required during titration $(\mathrm{mL})$ and $\mathrm{Ar}_{\mathrm{N}}$, the atomic weight of nitrogen $\left(14.007 \mathrm{~g} \cdot \mathrm{mol}^{-1}\right)$.

TAN rejection was calculated using Equation 5.

$$
R_{T A N}(\%)=100-\frac{C_{T A N, \text { permeate }}}{C_{\text {TAN,feed }}} \times 100
$$

Where $R_{T A N}(\%)$ is the total ammonia nitrogen rejection (\%); $C_{T A N, \text { permeate }}$ is the concentration $\left(\mathrm{mg} \cdot \mathrm{L}^{-}\right.$

${ }^{1}$ ) in the obtained permeate and $C_{T A N, \text { feed }}$ is the concentration $\left(\mathrm{mg} \cdot \mathrm{L}^{-1}\right)$ in the feed bulk.

\subsection{Membrane surface inspection after fouling-rinsing cycles}

\section{Membrane morphology and elemental composition}

Post mortem membrane morphology characterization and inorganic analysis were done on pristine and fouled-rinsed membranes, using a Scanning Electron Microscope (SEM, Jeol JSM6300) coupled with a X-ray detector (Oxford Instruments) for Energy-Dispersive X-Ray (EDX) analysis. Membrane surfaces were prepared for analysis by carbon sputtering (Sputter SCD 005, Bal-Tec, Leica Microsystems). Liquid nitrogen was used to obtain smooth cuts of the membrane crosssection. The SEM condenser lens (CL) was adjusted to 10 (coarse) during EDX analysis. The acceleration voltage was set at 10 and $20 \mathrm{kV}$ and the working distance was $15 \mathrm{~mm}$. The micrograph magnification was adjusted between 10 and 20k during the examinations. The image processing time was approximately 100 seconds. Between two and five iterations were required for the analysis. SEM-EDX results are given as an average of at least three different membrane sites. 


\section{Membrane organic composition}

Fourier Transform Infrared-Attenuated Total Reflectance (FTIR-ATR) (Platinum ATR integrated in Tensor 27, Bruker) was used to examine the organic composition on active and support layers from pristine and fouled-rinsed membranes. The angular setting for the laser tip on the ATR crystal was 45 degrees. Spectra were obtained for the band region $3996-599 \mathrm{~cm}^{-1}$, using 32 scans and $4 \mathrm{~cm}^{-}$ ${ }^{1}$ resolution. The obtained FTIR-ATR results are a combined IR spectrum for the TFC membrane [36], [37].

\subsection{Statistical analysis}

An Excel-based error minimization algorithm [34] was used to determine the membrane parameters $A$ (water permeability coefficient), $B$ (solute permeability coefficient) and $S$ (structural parameter). Results from FO experiments and chemical analysis were statistically analyzed using the Microsoft Excel@ data analysis work package. Average values, standard deviations, coefficients of variation and ANOVA single factor for significance tests were performed.

\section{Results and discussion}

\subsection{Determination of membrane characteristics}

Figure 2 a) shows $J_{w}$ for an increasing concentration of $\mathrm{NaCl}$ in the DS. $J_{w}$ follows a non-linear trend as the $\mathrm{NaCl}$ bulk solution concentration increases. This tendency suggests a limitation in membrane permeability at increasing $\mathrm{NaCl}$ concentrations, meaning that the dilutive external $\mathrm{CP}$ on the permeate side of the membrane significantly reduces the osmotic driving force [38]. Observing Figure $2 \mathrm{~b}$ ), membrane $J_{s}$ also increases in a non-linear trend, although the ratio $J_{s} / J_{w}$ remains relatively constant at $0.71 \pm 0.1 \mathrm{~g} / \mathrm{L}$. This suggests that at an increased $\mathrm{NaCl}$ concentration, the internal membrane properties remain constant. The interdependent relationship between the 
membrane characteristics and the DS should be taken into account to achieve a desirably low $J_{s} / J_{w}$ [39].

The membrane intrinsic characteristics described by the transport $(A$ and $B)$ and structural $(S)$ parameters were obtained following the method presented by Tiraferri et al. [34]. The membranes used in this study presented an A value of $0.18 \pm 0.02\left(\mathrm{~L} \cdot \mathrm{m}^{-2} \cdot \mathrm{h}^{-1} \cdot \mathrm{bar}^{-1}\right)$, B of $0.11 \pm 0.02\left(\mathrm{~L} \cdot \mathrm{m}^{-2} \cdot \mathrm{h}^{-1}\right)$ and $\mathrm{S}$ of $292 \pm 4.9 \mu \mathrm{m}$.

\subsection{Water flux $\left(J_{w}\right)$ and osmotic pressure difference $(\Delta \pi)$ during fouling}

Figure 3 shows the behavior of water flux $\left(J_{w}\right)$ as a function of processing time. Figure 3 a) and b) shows the membrane $J_{w}$ behaviour using $\mathrm{NaCl}$ model DS at two different concentrations for nonacidified and acidified FS. On the one hand, it can be observed that experiments using a lower DS concentration $(1.1 \mathrm{M})$ had a lower initial $J_{w}\left(4.4 \mathrm{~L} \cdot \mathrm{m}^{-2} \cdot \mathrm{h}^{-1}\right)$, while experiments using a $3.5 \mathrm{M} \mathrm{NaCl}$ model solution had a higher initial $J_{w}\left(8.5 \mathrm{~L} \cdot \mathrm{m}^{-2} \cdot \mathrm{h}^{-1}\right)$. This result was expected as higher $\mathrm{NaCl}$ concentration in DS lead to higher $J_{w}$. However, the final $J_{w}$ averaged $3.2 \mathrm{~L} \cdot \mathrm{m}^{-2} \cdot \mathrm{h}^{-1}$ for both DS concentrations, indicating that the decay rate in $J_{w}$ was larger when using a higher $\mathrm{NaCl}$ concentration $(3.5 \mathrm{M})$. This is in accordance with previous studies, in which an increase in initial $J_{w}$ due to a higher osmotic pressure difference promoted a higher convective flow of foulants towards the membrane surface [40], [41]. Other authors [42] also found that a higher initial $J_{w}$ could enhance a higher fouling propensity and a lower ultimate $J_{w}$. When using $3.5 \mathrm{M} \mathrm{NaCl}$ solutions, a more severe "dilutive" ICP occurs in FO mode, as it is shown in this study. $J_{w}$ becomes in this case sharply limited by the strong dilution of the DS within the support layer due to a higher water permeation from the feed towards the support layer when using higher DS concentrations [43][38][18]. In view of these results, one should consider that high concentrations in DS may improve $J_{w}$, although this improvement simultaneously enhances ICP and promotes the deposition of foulants on the membrane active layer as well. 
Acidification of the digestate FS did not influence the initial $J_{w}$ significantly in the experiments using $\mathrm{NaCl}$ as a DS (Figure 3 a) and b)). This has been previously observed on TFC reverse osmosis (RO) membranes processing acidified raw slurry [44]. However, acidification did have a negative effect on the final $J_{w}$ for those experiments using a higher DS concentration, as shown in Figure $3 b)$.

For those experiments using HPWW as a DS (Figure $3 \mathrm{c}, \mathrm{d}$ ), the initial $J_{w}$ (on average $8.5 \mathrm{~L} \cdot \mathrm{m}^{-2} \cdot \mathrm{h}^{-}$ ${ }^{1}$ ), was not significantly influenced by the type of DS pretreatment (i.e. desulfurization or prolonged aeration), indicating a similar behavior when using either DS pretreatment. However, acidification of the FS did affect $J_{w}$ negatively when using both HPWW pretreated DS. In Figure $3 \mathrm{c}$ ) and d), it can be observed that the final $J_{w}$ was two times higher in the experiments using non-acidified FS compared to those using acidified FS. This result was not obvious in experiments using acidified FS and $\mathrm{NaCl}$ as DS (Figure 3 a) as explained earlier in this section. In this regard, FS acidification only affected $J_{w}$ negatively in experiments using $3.5 \mathrm{M} \mathrm{NaCl} . J_{w}$ in experiments using a less concentrated DS (i.e. 1.1 $\mathrm{M} \mathrm{NaCl}$ ) was similar for experiments using acidified and non-acidified FSs. One possible explanation for the lower final $J_{w}$ when using acidified FS in combination with highly concentrated DSs, could be the decrease in water activity, caused by an increased ionic strength in the feed matrix after acidification [45], due to the higher concentration in sulfate ions and protons coming from the addition of sulfuric acid. Moreover, acidification improves ammonia (TAN) retention [44] in the feed matrix, which further increases the osmotic pressure in the FS. Additionally, effluents with increased ionic strength have previously been correlated to increased fouling [46], [47], which could be related to a reduction in hydration, size and charge of proteins in the fouling layer [48], resulting in a denser deposit which ultimately reduces the permeation across the membrane. This indicates that FS acidification in combination with high DS concentrations (for both $3.5 \mathrm{M} \mathrm{NaCl}$ and HPWW) might have a detrimental effect on membrane fouling. 
Figure 4 shows the effect of osmotic pressure gradient $(\Delta \pi)$ between FS and DSs, on the average water permeability $(K)$. The average $K$ for those experiments using $3.5 \mathrm{M} \mathrm{NaCl}$ and HPWW as DSs are comparable. Further, it can be observed that acidification of the FS in these experiments did not affect significantly $K$ during the studied experimental period. However, as presented earlier in this section, FS acidification caused a decrease in the final $J_{w}$ compared to those experiments where non-acidified FS was used. As shown in Figure 4 and previously suggested in Figure 3 a) and b), the highest $K$ is achieved in experiments using low DS concentrations (i.e. $1.1 \mathrm{NaCl}$ ), independently of the FS pretreatment. The higher $K$ in this case is explained by the milder foulant attraction towards the membrane active layer, observed when using lower concentrations in the DS (i.e. 1.1M $\mathrm{NaCl})$.

\subsection{Rejection of Total Ammonia-Nitrogen (TAN)}

As shown in Figure 5 (a) and b), TAN rejection is higher than $95.5 \%$ on average for all experiments, without significant differences for those experiments using FS acidification and independently of the obtained water fluxes, which have been previously described in section 3.2. It was observed that during the 12-hour alternating fouling-rinsing cycles experiment (Figure 5, b), the $\mathrm{pH}$ in the $\mathrm{NaCl} \mathrm{DS}$ increased over time from $\mathrm{pH} 5.8$ to a $\mathrm{pH} 8.7$ (data not shown). This $\mathrm{pH}$ increase could be related to leaching of $\mathrm{OH}^{-}$groups from the FS ( $\mathrm{pH} 8.4$, Table 1) towards the DS. At high $\mathrm{pH}$, due to the existing equilibrium between ammonium $\left(\mathrm{NH}_{4}{ }^{+}\right)$and ammonia $\left(\mathrm{NH}_{3}\right)$, TAN is mostly present as uncharged ammonia $\left(\mathrm{NH}_{3}\right)$ [49], similar in size and charge to water. Contrarily, at low $\mathrm{pH}$, the TAN is mostly present as charged ammonium $\left(\mathrm{NH}_{4}{ }^{+}\right)$and a higher TAN rejection is to be expected as observed by Masse et al. [44] during raw pig slurry separation using RO membranes. In their study, the authors relate TAN rejection to the concentration of $\mathrm{NH}_{4}{ }^{+}$versus the concentration of uncharged $\mathrm{NH}_{3}$, where the positively charged $\mathrm{NH}_{4}{ }^{+}$had more difficulty in penetrating the $\mathrm{RO}$ membrane, partly due to charge repulsion on the membrane surface. In the present scenario of FO using digestate LFs as a FS and 
$\mathrm{NaCl}$ solution as a DS, at the relatively stable FS pH of 8.4, the uncharged $\mathrm{NH}_{3}$ present in the FS will be able to permeate freely through the FO membrane, leading to an increase in the DS pH over time. As the $\mathrm{pH}$ of the DS increases, the permeation of $\mathrm{NH}_{3}$ towards the DS declines due to ionic equilibrium at the membrane surface. This mechanism explains the increase in TAN rejection over time, from $97.6 \%$ to $99.1 \%$ rejection (Figure $5, \mathrm{~b}$ ).

\subsection{Alternating membrane fouling and rinsing cycles}

Figure 6 shows the effect of rinsing on $J_{w}$ (Figure 6 a) and on the osmotic pressure gradient, $\Delta \pi$ (Figure $6 \mathrm{~b}$ ) over the 12-hour alternating fouling-rinsing cycles experiment. The initial $J_{w}$ could be successfully recovered (Figure 6 a)) after rinsing the membrane surface and allowing the membrane to soak overnight in DI water (fouling-rinsing cycle 1). $\Delta \pi$ decreased over the 12 - hour experiment (Figure $6 \mathrm{~b}$ )), due to dilution of the DS, although a plateau-behavior in $\Delta \pi$ was observed after 8 hours of experiment. However, this reduction in $\Delta \pi$ was not detrimental for the $J_{w}$ during foulingrinsing cycle 2 , when compared to the initial $J_{w}$ before the fouling-rinsing cycle started. The final $J_{w}$ achieved at the end of the fouling-rinsing cycle 3 was $34 \%$ lower than the initial $J_{w}$. A possible explanation for the $J_{w}$ recovery after the $1^{\text {st }}$ and $2^{\text {nd }}$ rinsing could be related to the nature of the formed fouling layer. The composition of the digestate LF forms unstable, flocculating suspensions that produce porous cake layers, resulting in alleviated flux decline and higher stabilized fluxes, even though effluents, such as digestates, have been previously related to increased fouling [46], [47]. These loosely attached digestate fouling layers, however, can be easily removed by increasing shear at the membrane surface [50], [51], which was achieved by membrane rinsing in between the three fouling cycles (Figure $6 \mathrm{c}-\mathrm{f}$ ). The alternating fouling and rinsing cycles indicated that the membrane stability could be maintained during the studied period. Extended FO concentration periods with alternating fouling and rinsing cycles would reveal the membrane stability in the longterm. 


\subsection{Membrane surface characterization}

Membrane inspection using SEM-EDX (Figure 7 and Figure 8) shows differences between the fouling layer formed on the membrane AL when using both acidified FS (Figure $7 \mathrm{~d}$ ), e), h)) and the non-acidified FS (Figure $7 \mathrm{f}$ ) and g)). Membranes exposed to the acidified FS presented more intense fouling deposits as compared to those membranes exposed to the non-acidified FS. This observation is also supported by $J_{w}$ data. As described in section 3.2, processing of acidified FS lead to a denser deposit compared to that formed when using a non-acidified FS. Regarding the use of different DS, micrographs of rinsed membrane support layers in contact with DS showed no major differences between membranes using $\mathrm{NaCl}$ or HPWW (Figure 7 i) - detail of DS crystal deposit).

Figure 8 shows the average elemental composition of the examined membranes obtained by EDX analysis. The mild inorganic-based deposits found on the examined membrane surfaces were very heterogeneous, in view of the high standard deviation from the relative elemental distribution. The presence of carbon $(\mathrm{C})$, sulfur $(\mathrm{S})$ and oxygen $(\mathrm{O})$ reveals the organic nature of the membranes and the FS. Traces of calcium $(\mathrm{Ca})$, magnesium $(\mathrm{Mg})$, iron $(\mathrm{Fe})$ and zinc $(\mathrm{Zn})$ throughout the examined membrane surfaces are also related to the nature of the digestate FS (Table 2) [8]. Crystals found in the support membrane layer (Figure 7 i) were formed mainly by sodium (Na), Ca and S, suggesting the presence of metal sulfates of $\mathrm{Ca}$ or $\mathrm{Fe}$ and $\mathrm{NaCl}$ in $\mathrm{HPWW}$; while deposits of $\mathrm{Fe}$ could further reveal the composition of tannery wastewater [52].

FTIR-ATR spectra from pristine and fouled-rinsed membranes are presented in Figure 9. Spectra show peaks attributed to both the PA-based selective AL and a PSf-based SL, with a characteristic fingerprint typically found in TFC materials based on PA-PSf [36]. Regarding the main

composition of the $\mathrm{AL}$, a strong peak at $1650 \mathrm{~cm}^{-1}(\mathrm{C}=\mathrm{O}$ stretching of amide $\mathrm{I}$ band $)$ together with a peak at $1610 \mathrm{~cm}^{-1}$ (hydrogen-bonded $\mathrm{C}=\mathrm{O}$ stretching vibrations) and at $1550 \mathrm{~cm}^{-1}(\mathrm{C}-\mathrm{N}$ stretching 
of amide II band) reveal characteristic peaks of PA [53], [54], while the intense absorption band at $3600-2800 \mathrm{~cm}^{-1}$ can be assigned to the aquaporin lipid region and the $\mathrm{CH}_{2}$-lipid and protein group [55]. Within this specific region, a primary absorption peak at $3271 \mathrm{~cm}^{-1}$ corresponds to N-H stretch for primary and secondary amines and amides $\left(3400-3250 \mathrm{~cm}^{-1}\right)$. The $\mathrm{O}-\mathrm{H}$ stretch from carboxylic acids corresponds to the band $3300-2500 \mathrm{~cm}^{-1}$ and $\mathrm{OH}$ stretch bonded and non-bonded groups appear at 3400-3300 $\mathrm{cm}^{-1}$ [56]. Moreover, the presence of aquaporins in the examined membranes is further confirmed with phosphodiester groups, found in membrane phospholipids $\left(1240 \mathrm{~cm}^{-1}\right)$ [55]. The specific functional groups of the PSf substrate layer in the TFC membranes appear at peaks $1150 \mathrm{~cm}^{-1}$ (symmetric $\mathrm{SO}_{2}$ stretching vibration), at $1321-1296 \mathrm{~cm}^{-1}$ (asymmetric $\mathrm{SO}_{2}$ stretching), $1240 \mathrm{~cm}^{-1}$ (asymmetric C-O-C stretching vibration), $1487 \mathrm{~cm}^{-1}\left(\mathrm{CH}_{3}-\mathrm{C}-\mathrm{CH}_{3}\right.$ stretching C-C in-ring bond in aromatic compounds) and 1410-1400 $\mathrm{cm}^{-1}(\mathrm{C}=\mathrm{C}$ aromatic ring stretching) [30], [46], [49]. Moreover, the presence of band $1583-1545 \mathrm{~cm}^{-1}$ (amino scissoring groups of primary amines), could further reveal protein deposits as part of fouling residues in rinsed membranes [58]. Finally, two distinctive absorption bands were found in pristine membranes $\left(2366-2335 \mathrm{~cm}^{-1}\right)$ and in rinsed membranes $\left(970-960 \mathrm{~cm}^{-1}\right)$. In pristine membranes, the detection of P-H phosphine bonds $\left(2360 \mathrm{~cm}^{-1}\right)$ could be related to the presence of polyhexamethylene guanidine phosphate, salt found in biocidal disinfectants, although this peak disappeared after the membrane fouling-rinsing cycles (Figure $9 \mathrm{~b})$ ). In rinsed membranes, the peak found at $970-960 \mathrm{~cm}^{-1}$ (C-O frequency) could further indicate the presence of polysaccharides and carbohydrate residues [55].

\section{Conclusions}

The present study evaluated the use of aquaporin-based forward osmosis membranes during separation of digestate LFs. Two draw solutions were used, namely $\mathrm{NaCl}(1.1$ and $3.5 \mathrm{M} \mathrm{NaCl})$ and a highly saline hide preservation (HPWW) wastewater source from tannery industry. Ammonia- 
nitrogen rejection and acidification of the digestate LFs and its effect on membrane performance and fouling was also investigated. The results showed that:

1. DSs with high osmotic potential (3.5M NaCl and HPWW) were detrimental for the water permeability due to an increased foulant convection towards the membrane active layer. However, this effect becomes less severe along the fouling process considering the final $J_{w}$ while using $\mathrm{NaCl}(1.1 \mathrm{M}$ and $3.5 \mathrm{M})$ or HPWW

2. Acidification of the FS increased fouling and accelerated the decline in $J_{w}$ for experiments using a DS with high osmotic potential (3.5 M NaCl and HPWW)

3. Particle deposition and the formation of a porous fouling cake layer were the governing fouling mechanisms

4. Total ammonia nitrogen (TAN) rejection was $\geq 95.5 \%$ for all experiments, regardless the use of acidification in the FS and the nature of the DS (NaCl or HPWW)

5. Membrane rinsing after fouling showed successful recovery of the membrane initial $J_{w}$ as well as removing the remaining fouling layer

6. Membrane surface characteristics after rinsing, showed that fouling was mild and reversible and the pristine membrane characteristics were practically recovered after rinsing. Further investigations on the removal of the remaining inorganic fouling by chemical cleaning could be considered for real applications

The present study demonstrated the applicability of aquaporin-based FO membranes with digestate LFs. An outstanding ammonia-nitrogen rejection and practically full recovery of pristine membrane characteristics after fouling-rinsing cycles were obtained. This supports the applicability of aquaporin-based FO membranes in applications where high TAN rejections are needed. Further investigations to support the use of aquaporin-based FO membranes in applications focusing on obtaining concentrated fertilizers from digestate LF for agriculture could also be considered. 


\section{Acknowledgments}

The authors thank the tannery factory in the region of Murcia (Spain) for providing the wastewater samples as well as Depuración de Aguas del Mediterráneo (DAM) for funding the forward osmosis project. Thanks to August Bonmatí from IRTA - GIRO Joint Research Unit IRTA-UPC, for providing the digestate liquid fractions, to Rebeca Vidal-Pérez as student assistant during the chemical analysis and to the Electron Microscopy Service from the Polytechnic University of Valencia (UPV, Spain). The authors further acknowledge funding from People Programme (Marie Curie Actions) of the European Union Seventh Framework Programme FP7/2007-2013/ under REA grant agreement $\mathrm{n}^{\circ}$ [289887].

\section{References}

[1] J. B. Holm-Nielsen, T. Al Seadi, and P. Oleskowicz-Popiel, "The future of anaerobic digestion and biogas utilization," Bioresour. Technol., vol. 100, no. 22, pp. 5478-5484, 2009.

[2] M. Pöschl, S. Ward, and P. Owende, "Evaluation of energy efficiency of various biogas production and utilization pathways," Appl. Energy, vol. 87, pp. 3305-3321, 2010.

[3] Y. Yan, Z. Zhang, L. Zhang, Y. Chen, and Q. Tang, "Dynamic Modeling of Biogas Upgrading in Hollow Fiber Membrane Contactors," Energy Fuels, no. 28, p. 5745-5755, 2014.

[4] Z. Zhang, F. Chen, and M. Rezakazemi, "Chemical Engineering Research and Design Modeling of a CO 2 -piperazine-membrane," Chem. Eng. Res. Des., vol. 131, pp. 375-384, 2017.

[5] M. Hjorth, M. L. Christensen, and P. V. Christensen, "Flocculation, coagulation, and 
precipitation of manure affecting three separation techniques," Bioresour. Technol., vol. 99, no. 18, pp. 8598-8604, 2008.

[6] L. Thörneby, K. Persson, and G. Trägårdh, "Treatment of Liquid Effluents from Dairy Cattle and Pigs using Reverse Osmosis," J. Agric. Eng. Res., vol. 73, no. 2, pp. 159-170, 1999.

[7] L. Masse, D. I. Masse, V. Beaudette, and M. Muir, "Size distribution and composition of particles in raw and anaerobically digested swine manure," Trans. ASAE, vol. 48, no. 5, pp. 1943-1949, 2005.

[8] M. S. Camilleri-Rumbau, "Development of membrane technology for production of concentrated fertilizer and clean water. $\mathrm{PhD}$ thesis,"University of Southern Denmark, 2015.

[9] R. López-Fernández, C. Aristizábal, and R. Irusta, "Ultrafiltration as an advanced tertiary treatment of anaerobically digested swine manure liquid fraction: A practical and theoretical study," J. Memb. Sci., vol. 375, no. 1-2, pp. 268-275, Jun. 2011.

[10] L. Masse, D. I. Masse, and Y. Pellerin, "The use of membranes for the treatment of manure: a critical literature review," Biosyst. Eng., vol. 98, no. 4, pp. 371-380, 2007.

[11] D. Fangueiro, M. Hjorth, and F. Gioelli, "Acidification of animal slurry- a review," $J$. Environ. Manage., vol. 149, pp. 46-56, 2015.

[12] M. S. Camilleri-Rumbau, L. Masse, J. Dubreuil, M. Mondor, K. V. Christensen, and B. Norddahl, "Fouling of a spiral-wound reverse osmosis membrane processing swine wastewater: Effect of cleaning procedure on fouling resistance," Environ. Technol. (United Kingdom), vol. 37, no. 13, 2016.

[13] M. Mondor, D. Ippersiel, F. Lamarche, and L. Masse, "Fouling characterization of electrodialysis membranes used for the recovery and concentration of ammonia from swine 
manure.," Bioresour. Technol., vol. 100, no. 2, pp. 566-71, Jan. 2009.

[14] S. Phuntsho, H. K. Shon, S. Hong, S. Lee, and S. Vigneswaran, “A novel low energy fertilizer driven forward osmosis desalination for direct fertigation: Evaluating the performance of fertilizer draw solutions," J. Memb. Sci., vol. 375, no. 1-2, pp. 172-181, 2011.

[15] A. Achilli, T. Y. Cath, E. A. Marchand, and A. E. Childress, "The forward osmosis membrane bioreactor: A low fouling alternative to MBR processes," Desalination, vol. 239, no. 1-3, pp. 10-21, 2009.

[16] Z. Wu, S. Zou, B. Zhang, L. Wang, and Z. He, "Forward osmosis promoted in-situ formation of struvite with simultaneous water recovery from digested swine wastewater," Chem. Eng. J., vol. 342, no. December 2017, pp. 274-280, 2018.

[17] J. R. McCutcheon and M. Elimelech, "Influence of concentrative and dilutive internal concentration polarization on flux behavior in forward osmosis," J. Memb. Sci., vol. 284, no. 1-2, pp. 237-247, 2006.

[18] G. T. Gray, J. R. McCutcheon, and M. Elimelech, "Internal concentration polarization in forward osmosis: role of membrane orientation," Desalination, vol. 197, no. 1-3, pp. 1-8, 2006.

[19] C. Y. Tang, Y. Zhao, R. Wang, C. Hélix-Nielsen, and A. G. Fane, "Desalination by biomimetic aquaporin membranes: Review of status and prospects," Desalination, vol. 308, pp. 34-40, 2013.

[20] S. Zhao, L. Zou, C. Y. Tang, and D. Mulcahy, "Recent developments in forward osmosis: Opportunities and challenges," J. Memb. Sci., vol. 396, pp. 1-21, 2012. 
[21] M. Haroun, A. Idris, and S. R. Syed Omar, "A study of heavy metals and their fate in the composting of tannery sludge,” Waste Manag., vol. 27, no. 11, pp. 1541-1550, 2007.

[22] J. A. Mendoza-Roca, M. V. Galiana-Aleixandre, J. Lora-García, and A. Bes-Piá, "Purification of tannery effluents by ultrafiltration in view of permeate reuse," Sep. Purif. Technol., vol. 70, no. 3, pp. 296-301, 2010.

[23] J. M. Morera, A. Bacardit, L. Ollé, E. Bartolí, and M. D. Borràs, "Minimization of the environmental impact in the unhairing of bovine hides," Chemosphere, vol. 72, no. 11, pp. 1681-1686, 2008.

[24] D. Castiello, M. Puccini, M. Seggiani, S. Vitolo, and F. Zammori, "Life cycle assessment (LCA) of the oxidative unhairing process by hydrogen peroxide," J. Am. Leather Chem. Assoc., vol. 103, no. 1, pp. 1-6, 2008.

[25] G. Lofrano, S. Meriç, G. E. Zengin, and D. Orhon, "Chemical and biological treatment technologies for leather tannery chemicals and wastewaters: A review," Sci. Total Environ., vol. 461-462, pp. 265-281, 2013.

[26] K. Windey, I. De Bo, and W. Verstraete, “Oxygen-limited autotrophic nitrificationdenitrification (OLAND) in a rotating biological contactor treating high-salinity wastewater," Water Res., vol. 39, no. 18, pp. 4512-4520, 2005.

[27] R. W. Holloway, A. E. Childress, K. E. Dennett, and T. Y. Cath, "Forward osmosis for concentration of anaerobic digester centrate," Water Res., vol. 41, no. 17, pp. 4005-4014, 2007.

[28] J. L. Soler-Cabezas, J. A. Mendoza-Roca, M. C. Vincent-Vela, M. J. Luján-Facundo, and L. Pastor-Alcañiz, "Simultaneous concentration of nutrients from anaerobically digested sludge centrate and pre-treatment of industrial effluents by forward osmosis," Sep. Purif. Technol., 
vol. 193, no. September 2017, pp. 289-296, 2018.

[29] M. Xie, L. D. Nghiem, W. E. Price, and M. Elimelech, “Toward Resource Recovery from Wastewater: Extraction of Phosphorus from Digested Sludge Using a Hybrid Forward Osmosis-Membrane Distillation Process,” Environ. Sci. Technol. Lett., vol. 1, no. 2, pp. 191$195,2014$.

[30] A. J. Ansari, F. I. Hai, W. E. Price, and L. D. Nghiem, "Phosphorus recovery from digested sludge centrate using seawater-driven forward osmosis," Sep. Purif. Technol., vol. 163, pp. $1-7,2016$.

[31] A. Akhiar, A. Battimelli, M. Torrijos, and H. Carrere, "Comprehensive characterization of the liquid fraction of digestates from full-scale anaerobic co-digestion," Waste Manag., vol. 59, pp. 118-128, 2017.

[32] M. S. Camilleri-Rumbau, B. Norddahl, J. Wei, K. V Christensen, and L. F. Sotoft, "Microfiltration and ultrafiltration as a post-treatment of biogas plant digestates for producing concentrated fertilizers," Desalin. Water Treat., vol. 55, no. 6, pp. 1639-1653, 2015.

[33] A. K. Pabby, S. Rizvi, and A. M. Sastre Requena, Eds., Handbook of Membrane Separations. Boca Raton: CRC Press, 2015.

[34] A. Tiraferri, N. Y. Yip, A. P. Straub, S. Romero-Vargas Castrillon, and M. Elimelech, “A method for the simultaneous determination of transport and structural parameters of forward osmosis membranes," J. Memb. Sci., vol. 444, pp. 523-538, 2013.

[35] Standard methods for the Examination of Water and Wastewater, 22nd ed. Washington: American Public Health Association (APHA), American Water Works Association (AWWA), Water Environment Federation (WEF), 1999. 
[36] A. P. Rao, S. V. Joshi, J. J. Trivedi, C. V. Devmurari, and V. J. Shah, "Structureperformance correlation of polyamide thin film composite membranes: Effect of coating conditions on film formation," J. Memb. Sci., vol. 211, no. 1, pp. 13-24, 2003.

[37] C. Y. Tang, Y. N. Kwon, and J. O. Leckie, "Effect of membrane chemistry and coating layer on physiochemical properties of thin film composite polyamide RO and NF membranes. I. FTIR and XPS characterization of polyamide and coating layer chemistry," Desalination, vol. 242, no. 1-3, pp. 149-167, 2009.

[38] J. R. McCutcheon, R. L. McGinnis, and M. Elimelech, "Desalination by ammonia-carbon dioxide forward osmosis: Influence of draw and feed solution concentrations on process performance," J. Memb. Sci., vol. 278, no. 1-2, pp. 114-123, 2006.

[39] J. Qin, W. C. L. Lay, and K. A. Kekre, "Recent developments and future challenges of forward osmosis for desalination : a review," Desalin. Water Treat., vol. 0, pp. 1-14, 2012.

[40] B. Mi and M. Elimelech, "Chemical and physical aspects of organic fouling of forward osmosis membranes," J. Memb. Sci., vol. 320, no. 1-2, pp. 292-302, 2008.

[41] Ming Xie, L. D. Nghiema, W. E. Price, and Menachem Elimelech, "Impact of organic and colloidal fouling on trace organic contaminant rejection by forward osmosis: Role of initial permeate flux," Desalination, vol. 336, pp. 146-152, 2014.

[42] E. A. Bell, R. W. Holloway, and T. Y. Cath, "Evaluation of forward osmosis membrane performance and fouling during long-term osmotic membrane bioreactor study," J. Memb. Sci., vol. 517, pp. 1-13, Nov. 2016.

[43] K. Lutchmiah, A. R. D. Verliefde, K. Roest, L. C. Rietveld, and E. R. Cornelissen, "Forward osmosis for application in wastewater treatment: a review.," Water Res., vol. 58, pp. 179-97, Jul. 2014. 
[44] L. Masse, D. I. Masse, and Y. Pellerin, "The effect of $\mathrm{pH}$ on the separation of manure nutrients with reverse osmosis membranes," J. Memb. Sci., vol. 325, no. 2, pp. 914-919, 2008.

[45] R. W. Baker., "Membrane Transport Theory," in Membrane Technology and Applications, John Wiley \& Sons, Ltd., 2004, pp. 15-87.

[46] W. S. Ang and M. Elimelech, "Protein (BSA) fouling of reverse osmosis membranes: Implications for wastewater reclamation," J. Memb. Sci., vol. 296, no. 1-2, pp. 83-92, 2007.

[47] S. Hong and M. Elimelech, "Chemical and physical aspects of natural organic matter (NOM) fouling of nanofiltration membranes," J. Memb. Sci., vol. 132, no. 2, pp. 159-181, 1997.

[48] H. Attia, M. Bennasar, and B. Tarodo de la Fuente, "Study of the fouling of inorganic membranes by acidified milks using scanning electron microscopy and electrophoresis. I. Membrane with pore diameter 0.2 um," J. Dairy Res., vol. 58, pp. 39-50, 1991.

[49] T. Yan, Y. Ye, H. Ma, Y. Zhang, W. Guo, B. Du, and Q. Wei, “A critical review on membrane hybrid system for nutrient recovery from wastewater," Chem. Eng. J., vol. 348, no. April, pp. 143-156, 2018.

[50] L. Masse, M. Mondor, G. Talbot, L. Deschênes, H. Drolet, N. Gagnon, F. St-Germain, and J. Puig-Bargués, "Fouling of Reverse Osmosis Membranes Processing Swine Wastewater Pretreated by Mechanical Separation and Aerobic Biofiltration,” Sep. Sci. Technol., vol. 49, no. 9 , pp. 1298-1308, 2014.

[51] Y. Yuan and J. E. Kilduff, "Effect of colloids on salt transport in crossflow nanofiltration,” J. Memb. Sci., vol. 346, no. 2, pp. 240-249, 2010.

[52] P. Bhattacharya, A. Roy, S. Sarkar, S. Ghosh, S. Majumdar, S. Chakraborty, S. Mandal, A. 
Mukhopadhyay, and S. Bandyopadhyay, "Combination technology of ceramic microfiltration and reverse osmosis for tannery wastewater recovery," Water Resour. Ind., vol. 3, pp. 48-62, Sep. 2013.

[53] J. Ren and J. R. McCutcheon, "A new commercial thin film composite membrane for forward osmosis," Desalination, vol. 343, pp. 187-193, 2014.

[54] D. Emadzadeh, W. J. Lau, T. Matsuura, M. Rahbari-Sisakht, and A. F. Ismail, “A novel thin film composite forward osmosis membrane prepared from $\mathrm{PSf}-\mathrm{TiO} 2$ nanocomposite substrate for water desalination," Chem. Eng. J., vol. 237, pp. 70-80, 2014.

[55] Z. Movasaghi, S. Rehman, and I. U. Rehman, "Fourier transform infrared (FTIR) spectroscopy of biological tissues," Appl. Spectrosc. Rev., vol. 43, no. 2, pp. 134-179, 2008.

[56] E. Smidt and K. Meissl, "The applicability of Fourier transform infrared (FT-IR) spectroscopy in waste management.," Waste Manag., vol. 27, no. 2, pp. 268-76, Jan. 2007.

[57] W. Ding, Y. Li, M. Bao, J. Zhang, C. Zhang, and J. Lu, "Highly permeable and stable forward osmosis (FO) membrane based on the incorporation of $\mathrm{Al}_{2} \mathrm{O}_{3}$ nanoparticles into both substrate and polyamide active layer," RSC Adv., vol. 7, no. 64, pp. 40311-40320, 2017.

[58] M. R. Provenzano, G. Iannuzzi, C. Fabbri, and N. Senesi, "Qualitative Characterization and Differentiation of Digestates from Different Biowastes Using FTIR and Fluorescence Spectroscopies,” J. Environ. Prot. (Irvine,. Calif)., vol. 2, no. 1, pp. 83-89, 2011. 


\section{Figures}

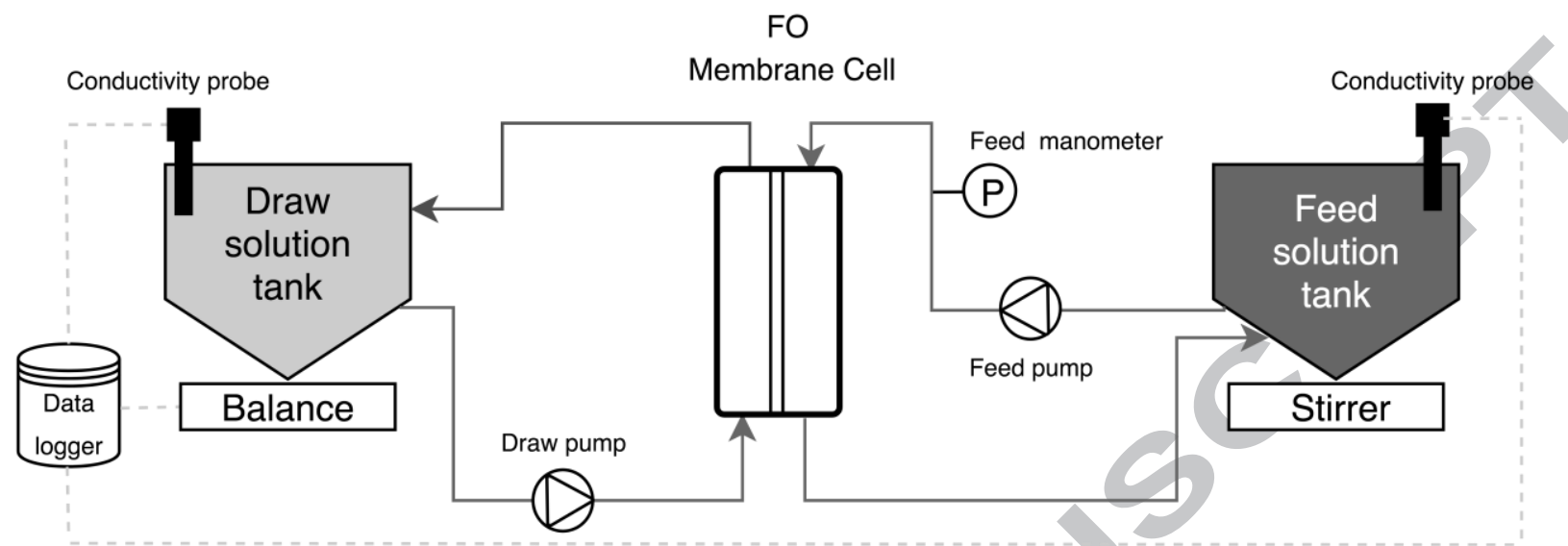

Figure 1: Laboratory scale plant for forward osmosis experiments 

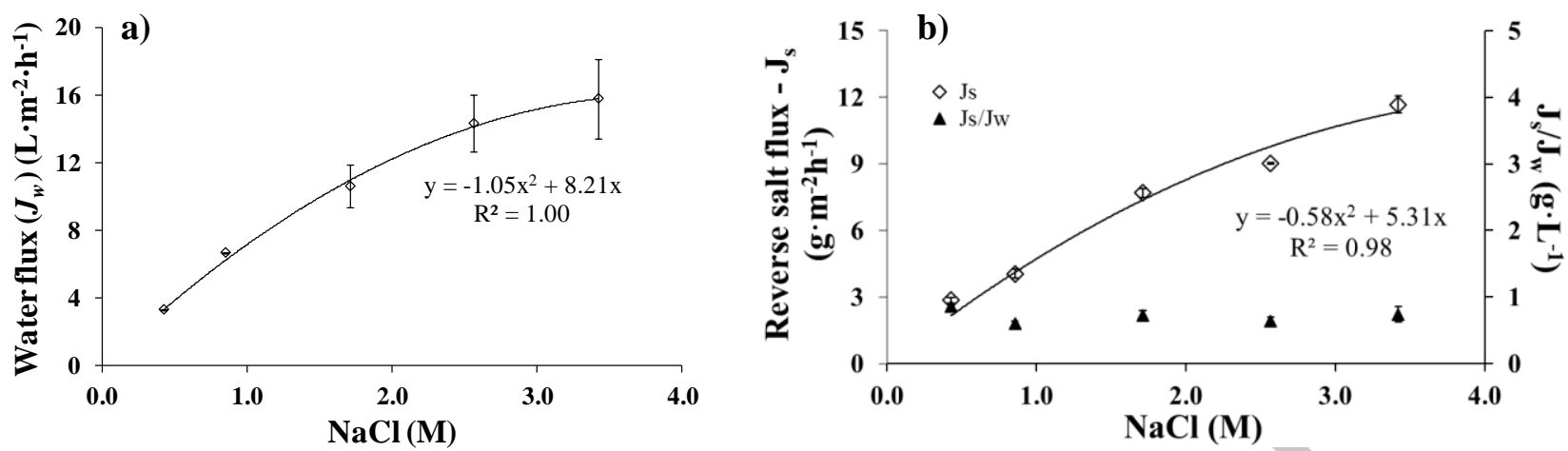

Figure 2: a) Water flux, $J_{w}, v s \mathrm{NaCl}$ concentration; b) reverse salt flux, $J_{s}$, and $J_{s} / J_{w}$ vs $\mathrm{NaCl}$ draw solution concentration 

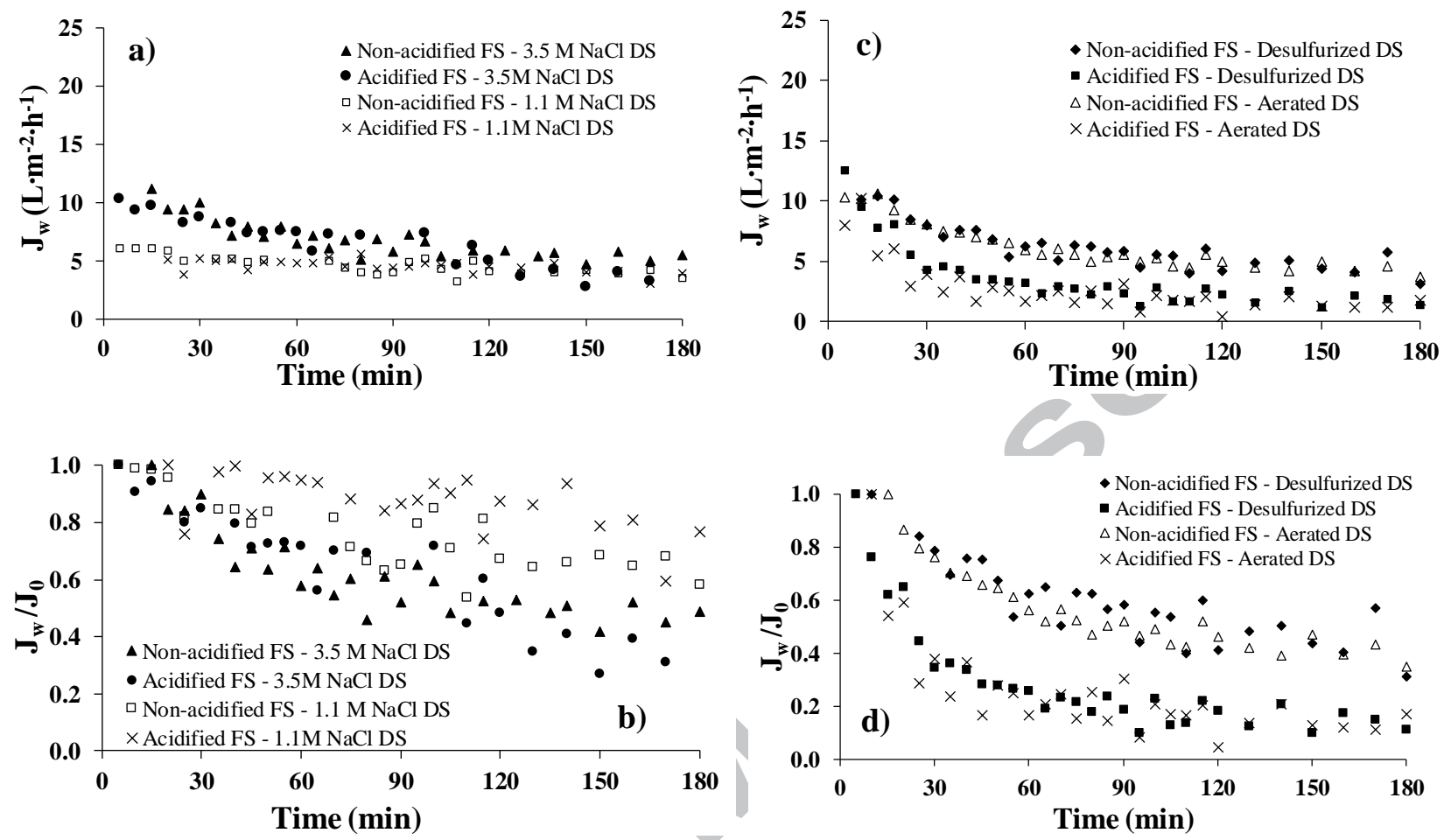

Figure 3: Absolute $\left(J_{w}\right)$ and normalized $\left(J_{w} / J_{0}\right)$ permeate flux using: a) - b) $\mathrm{NaCl}$ draw solution at two different concentrations (1.1 and 3.5 M) and c) - d) HPWW as a draw solution (desulfurized or aerated), using non-acidified and acidified feed solutions in both cases 

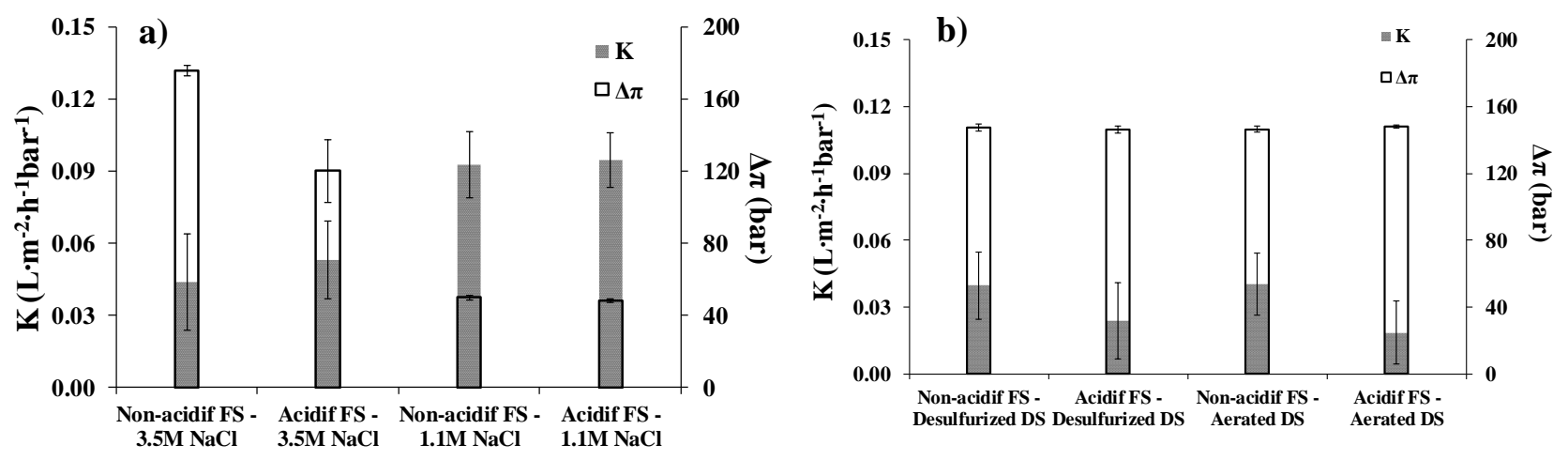

Figure 4: Permeability $(K)$ and osmotic pressure gradient $(\Delta \pi)$ during fouling experiments using a)

$\mathrm{NaCl}$ solution at two different concentrations (1.1 and 3.5 M) and b) HPWW as a draw solution

(desulfurized or aerated), using non-acidified and acidified feed solutions in both cases 
a)

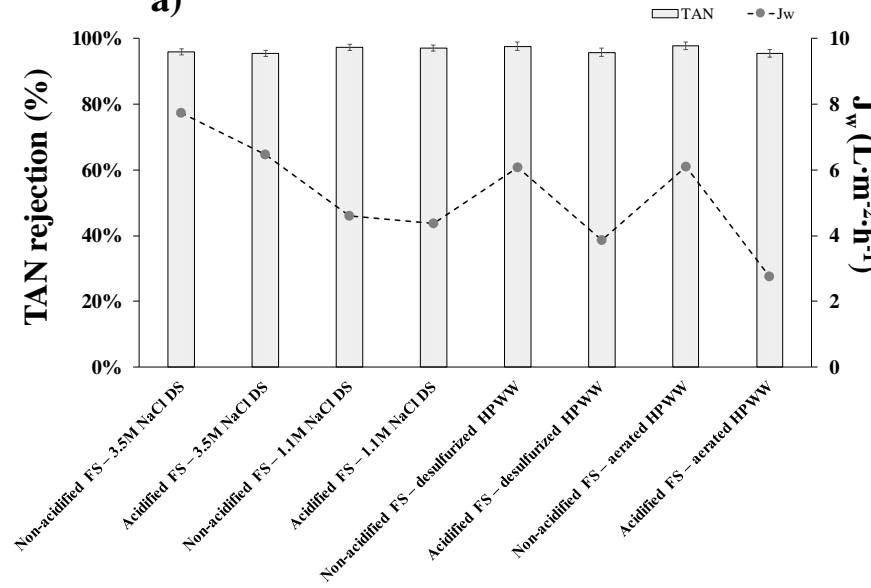

b)

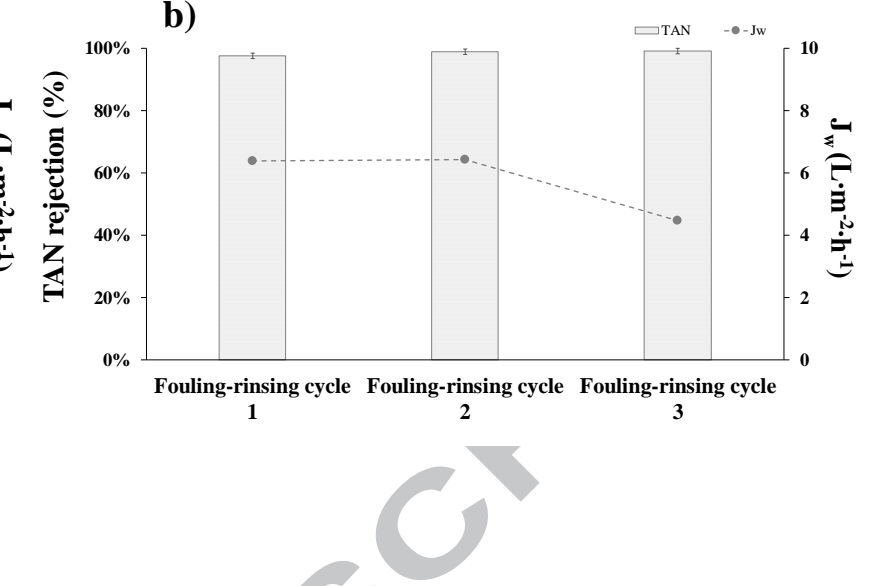

Figure 5: Average rejection of Total Ammonia Nitrogen (TAN) and the related average water flux $\left(\mathrm{J}_{\mathrm{w}}\right)$ for a) fouling experiments and b) alternating fouling-rinsing experiment 

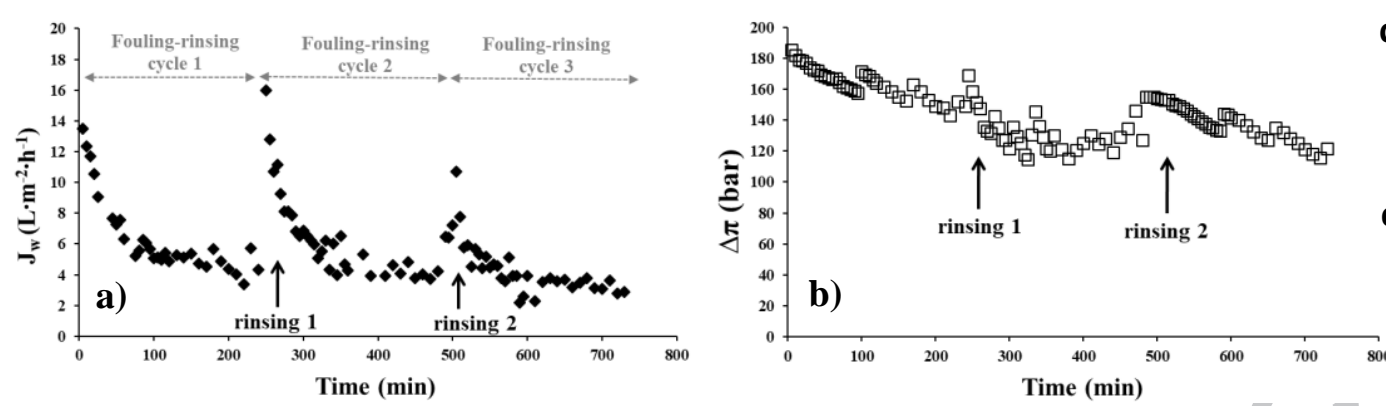

c)

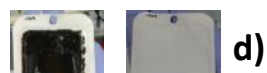

Figure 6: a) Water flux $\left(J_{w}\right) v s$ time and the corresponding b) osmotic pressure gradient $(\Delta \pi) v s$ time during alternating fouling-rinsing experiment. Pictures to the right show membrane coupon after undergoing 3 fouling-rinsing cycles: c) membrane fouled with FS digestate liquid fraction; d) membrane after rinsing 1, e) after rinsing 2 and f) after last rinsing (rinsing 3) 

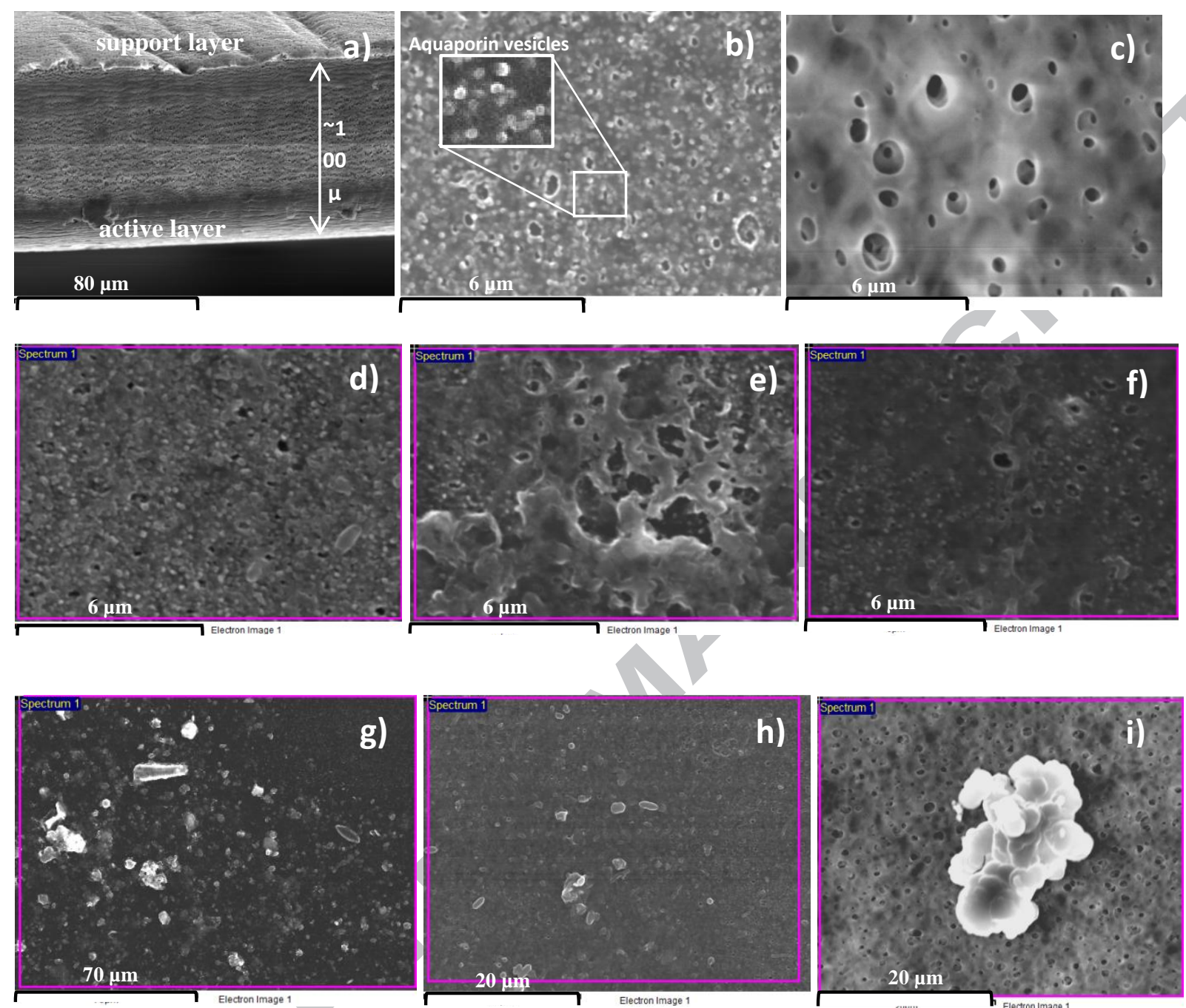

Figure 7: SEM images of aquaporin-based forward osmosis pristine membrane at $10 \mathrm{kV}$ a) crosssection (magnification $x 750)$, b) active layer $(\mathrm{AL})$ with incorporated aquaporin vesicles( $\sim 150 \mathrm{~nm})$ $(\mathrm{x} 10 \mathrm{k})$, c) support layer (SL) (x10k) - and examples of SEM images of rinsed membranes: d) AL (acidified feed and 3.5M NaCl) $(x 10 \mathrm{k}, 10 \mathrm{kV})$, e) $\mathrm{AL}$ (acidified feed and $1.1 \mathrm{M} \mathrm{NaCl})(\mathrm{x} \mathrm{10k}, 10 \mathrm{kV}), \mathrm{f})$ AL (non-acidified feed and 3.5M NaCl) $(x 10 \mathrm{k}, 10 \mathrm{kV}), \mathrm{g}) \mathrm{AL}$ (non-acidified feed and desulfurized HPWW) (x 800, 10kV), h) AL (acidified feed and desulfurized HPWW) (x 2500, 20kV), i) SL with detail of a crystal (acidified feed and 1.1M NaCl, similar crystals found for HPWW) (x 3000, 10kV) 


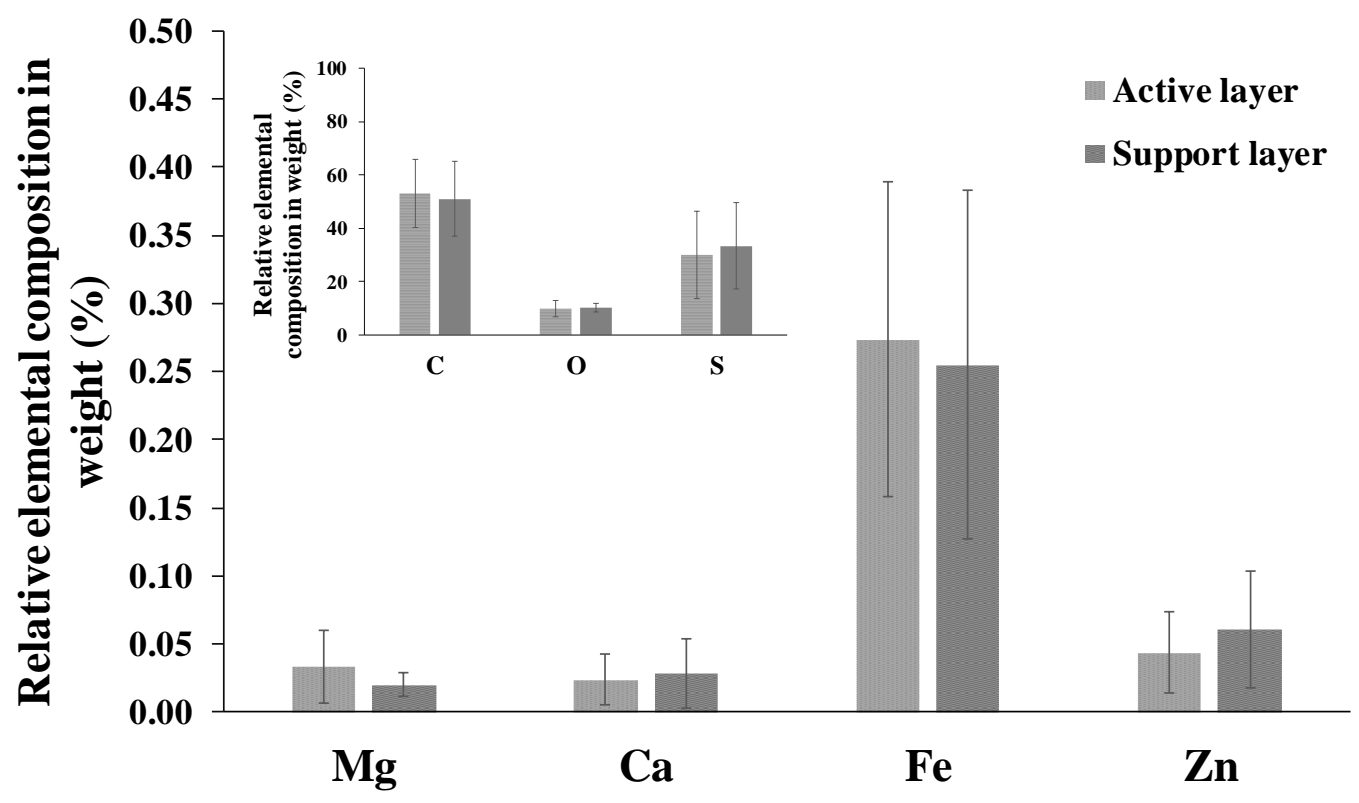

Figure 8: EDX analysis of the examined membrane surfaces (active layers and support layers) after membrane fouling-rinsing cycles 


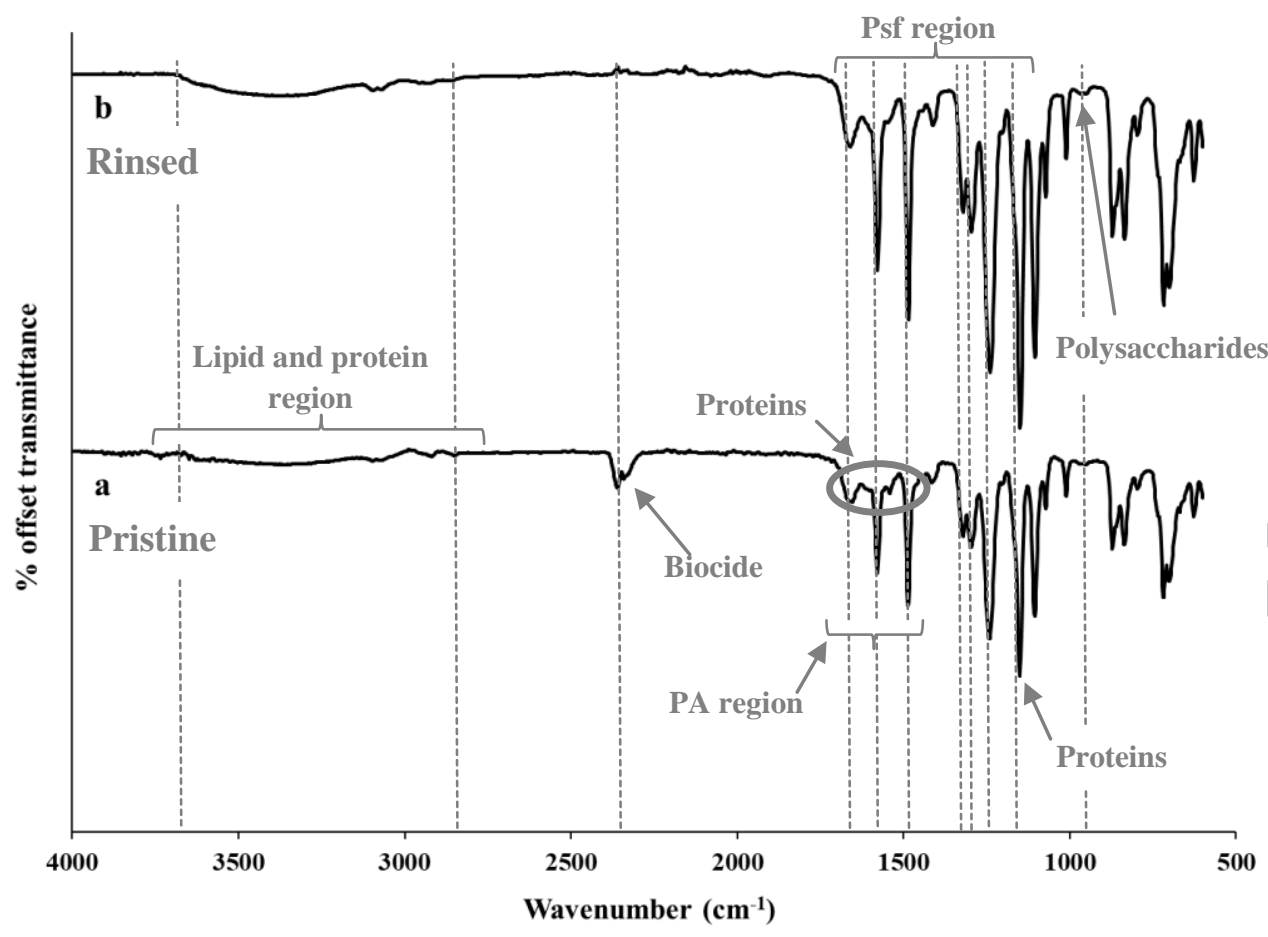

Figure 9: FTIR-ATR spectra of the a) pristine membrane and b) rinsed membranes (dashed lines refer to specific functional groups) 


\section{Tables}

Table 1: Characteristics of the feed solution and draw solution (SD shown as \pm value) $\left({ }^{\mathrm{a}}\right.$ Dilution factor

$2,{ }^{b}$ Including pre-treated desulfurized and aerated HPWW meshed at $60 \mu \mathrm{m}$ )

\begin{tabular}{llll}
\hline \multirow{2}{*}{ Parameter } & Feed solution & \multicolumn{2}{c}{ Draw solutions } \\
\cline { 2 - 4 } & Cow digestate liquid fraction & $\begin{array}{l}\text { Hide preservation } \\
\text { wastewater }(\text { HPWW }\end{array}$ & NaCl solution \\
\hline $\mathrm{pH}$ & $8.4(6.7$ when acidified) & $8.7-9.5$ & 6.25 \\
Conductivity $\left(\mathrm{mS} \cdot \mathrm{cm}^{-1}\right)$ & $9.2 \pm 0.4$ & $178 \pm 0.5$ & $87 \pm 0.3(1.1 \mathrm{M})$ \\
Total solids $\left(\mathrm{g} \cdot \mathrm{L}^{-1}\right)$ & $20 \pm 1.7^{\mathrm{a}}$ & $197 \pm 8^{\mathrm{b}}$ & $180 \pm 9(3.5 \mathrm{M})$ \\
Osmotic pressure $(\pi)(\mathrm{bar})$ & $1.3 \pm 0.3$ & $150 \pm 1(\sim 3.5 \mathrm{M}$ & -- \\
Soluble $\mathrm{COD}\left(\mathrm{mg} \cdot \mathrm{L}^{-1} \mathrm{O}_{2}\right)$ & 5,349 & equivalent $)$ & $51 \pm 0.3(1.1 \mathrm{M})$ \\
Total $\mathrm{NH}{ }_{3}-\mathrm{N}(\mathrm{TAN})\left(\mathrm{mg} \cdot \mathrm{L}^{-1}\right)$ & 2,477 & 3,338 & $161 \pm 15(3.5 \mathrm{M})$ \\
$\mathrm{NO}_{3}-\mathrm{N}\left(\mathrm{mg} \cdot \mathrm{L}^{-1}\right)$ & 14.5 & 353 & -- \\
$\mathrm{PO}_{4}{ }^{3-}-\mathrm{P}\left(\mathrm{mg} \cdot \mathrm{L}^{-1}\right)(\mathrm{after} 1.2 \mu \mathrm{m}$ & 17 & 26 & -- \\
$\mathrm{pre}-\mathrm{filter})$ & 7,580 & 26 & -- \\
$\mathrm{TOC}\left(\mathrm{mg} \cdot \mathrm{kg}^{-1}\right)$ & & 55.3 & -- \\
\hline
\end{tabular}


Table 2: Elemental analysis of the different fractions used (in g per kg of total solids) ( ${ }^{\mathrm{a}}$ Dilution factor 2, N.A. not available)

\begin{tabular}{|c|c|c|c|c|c|}
\hline \multirow{3}{*}{ Element } & \multirow{2}{*}{\multicolumn{3}{|c|}{ Cow digestate liquid fraction }} & \multicolumn{2}{|c|}{ Hide preservation wastewater } \\
\hline & & & & & HPWW) \\
\hline & Unmeshed & $\begin{array}{l}\text { Meshed } 125 \\
\mu^{\mathrm{a}}\end{array}$ & $\begin{array}{l}\text { Meshed } 125 \\
\mu \mathrm{m} \text { acidified }^{\mathrm{a}}\end{array}$ & Aerated & Desulfurized \\
\hline $\mathrm{Al}\left(\mathrm{g} \cdot \mathrm{kg}^{-1}\right)$ & 7.45 & 5.3 & 10.5 & 0.02 & 0.02 \\
\hline As $\left(\mathrm{mg} \cdot \mathrm{kg}^{-1}\right)$ & 0.004 & 0.006 & 0.01 & $<0.001$ & $<0.001$ \\
\hline $\mathrm{Ca}\left(\mathrm{g} \cdot \mathrm{kg}^{-1}\right)$ & 32.1 & 24.6 & 41.5 & N.A. & N.A. \\
\hline $\mathrm{Cd}\left(\mathrm{g} \cdot \mathrm{kg}^{-1}\right)$ & 0 & $<0.001$ & 0 & $<0.001$ & $<0.001$ \\
\hline $\mathrm{Co}\left(\mathrm{g} \cdot \mathrm{kg}^{-1}\right)$ & $<0.001$ & $<0.001$ & $<0.001$ & $<0.001$ & $<0.001$ \\
\hline $\mathrm{Cr}\left(\mathrm{g} \cdot \mathrm{kg}^{-1}\right)$ & 0.04 & 0.03 & 0.05 & N.A. & N.A. \\
\hline $\mathrm{Cu}\left(\mathrm{g} \cdot \mathrm{kg}^{-1}\right)$ & 0.25 & 0.18 & 0.37 & N.A. & N.A. \\
\hline $\mathrm{Fe}\left(\mathrm{g} \cdot \mathrm{kg}^{-1}\right)$ & 10.4 & 6.5 & 14.0 & 0.03 & 0.01 \\
\hline $\mathrm{K}\left(\mathrm{g} \cdot \mathrm{kg}^{-1}\right)$ & 29.7 & 36.5 & 38.1 & N.A. & N.A. \\
\hline $\operatorname{Mg}\left(g \cdot \mathrm{kg}^{-1}\right)$ & 8.47 & 3.7 & 19.7 & N.A. & N.A. \\
\hline $\operatorname{Mn}\left(g \cdot \mathrm{kg}^{-1}\right)$ & 0.70 & 0.45 & 1.4 & N.A. & 0.33 \\
\hline $\mathrm{Na}\left(\mathrm{g} \cdot \mathrm{kg}^{-1}\right)$ & 14.7 & 19.0 & 24.0 & 0.26 & 0.22 \\
\hline $\mathrm{Ni}\left(\mathrm{g} \cdot \mathrm{kg}^{-1}\right)$ & 0.02 & 0.02 & 0.03 & N.A. & N.A. \\
\hline $\mathrm{P}\left(\mathrm{g} \cdot \mathrm{kg}^{-1}\right)$ & 22.5 & 13.1 & 39.0 & N.A. & N.A. \\
\hline $\mathrm{S}\left(\mathrm{g} \cdot \mathrm{kg}^{-1}\right)$ & 10.7 & 7.2 & 80.4 & 0.01 & 0.01 \\
\hline $\mathrm{Zn}\left(\mathrm{g} \cdot \mathrm{kg}^{-1}\right)$ & 0.70 & 0.50 & 1.0 & 0.01 & 0 \\
\hline
\end{tabular}




\section{Highlights}

- Acidification of digestates caused increased fouling on aquaporin-based membranes

- Highly concentrated draw solutions caused a decline in osmotic water permeability

- Total ammonia nitrogen rejection was always $\geq 95.5 \%$

- Rinsing with deionized water recovered the pristine membrane characteristics

- Fouling of aquaporin-based membranes was mild and reversible 